\title{
BONE TURNOVER MARKERS IN PATIENTS WITH ISOLATED FEMORAL SHAFT FRACTURE UNDERGOING SYSTEMIC OZONE THERAPY
}

Osikov MV凶, Davidova EV, Abramov KS

South Ural State Medical University, Chelyabinsk, Russia

\begin{abstract}
Efferent physical therapy holds promise as an adjunct to the combination treatment of femoral fractures in young, working-age individuals. The aim of the study was to investigate the dynamics of bone turnover markers at different stages of femoral fracture consolidation in patients undergoing ozone therapy. The study enrolled 20 men (group 2, $47.8 \pm 3.5$ years) with a femoral shaft fracture (AO/ASIF 32A, 32B). The control group (group 1, $46.8 \pm 3.7$ years) comprised 10 healthy males. Subgroup $2 \mathrm{a}(n=10)$ was assigned to receive standard therapy; subgroup $2 \mathrm{~b}(n=10)$ was assigned to receive standard therapy complemented by minor autohemotherapy (MAHT) at $20 \mathrm{mg} / \mathrm{L}$ ozone concentrations. On days 7, 30 and 90, fracture consolidation was assessed on the RUST scale and blood levels of C-terminal telopeptides of type I collagen (bCTx, pg/ml) and procollagen type I carboxy-terminal propeptide (PICP, $\mathrm{ng} / \mathrm{ml}$ ) were measured. On day 7 , the total RUST score in subgroups $2 \mathrm{a}$ and $2 \mathrm{~b}$ was 4 points; on day 30, it was 6.5 and 8.7 points, respectively, and on day 90, it reached 10 and 11.5 points, respectively. Bone mineral density was as high as $90 \%$ in the MAHT subgroup vs. $78 \%$ in subgroup 2a, indicating faster bone healing. On day 30 , bCTx levels in subgroup $2 \mathrm{~b}$ were higher than in subgroup 2a (2289.4 [2145.3; 2365.4] vs. 1894.6 [1745.3; 2098.2], respectively. On day 7, PICP was significantly elevated in subgroup $2 b$ in comparison with subgroup 2a; its levels peaked on days 30 and 90 (day 30: 268.3 [231.2; 286.3] vs. 183.2 [174.6; 195.6]; day 90: 584.6 [512.3; 589.3 ] vs. 351.2 [312.3; 369.4]. Thus, MAHT produces a positive effect on the quality and intensity of bone healing in men with isolated closed femoral shaft fractures.
\end{abstract}

Keywords: closed isolated femoral shaft fracture, ozone therapy, bone remodeling

Author contribution: Osikov MV conceived the study, proposed its design, analyzed the obtained data, wrote and edited the manuscript; Davidova EV conceived the study, proposed its design, analyzed the obtained data, participated in writing the manuscript; Abramov KS collected clinical data, analyzed the results of the study, wrote and edited the manuscript. The authors equally contributed to the study and preparation of the manuscript, read and approved the final version of this article before publication.

Compliance with ethical standards: the study was approved by the Ethics Committee of the South Ural State Medical University, Chelyabinsk (Protocol № 4 dated May 22, 2020). Informed consent was obtained from all study participants.

$\triangle$ Correspondence should be addressed: Mikhail V. Osikov

Vorovskogo, 64, Chelyabinsk, 454092; prof.osikov@yandex.ru

Received: 29.12.2020 Accepted: 17.01.2021 Published online: 02.02.2021

DOI: $10.24075 /$ brsmu.2021.003

\section{МАРКЕРЫ РЕМОДЕЛИРОВАНИЯ КОСТНОЙ ТКАНИ ПРИ КОНСОЛИДАЦИИ ИЗОЛИРОВАННОГО ПЕРЕЛОМА БЕДРЕННОЙ КОСТИ В УСЛОВИЯХ СИСТЕМНОЙ ОЗОНОТЕРАПИИ}

М. В. Осиков $\bowtie$ Е. В. Давыдова, К. С. Абрамов

Южно-Уральский государственный медицинский университет, Челябинск, Россия

В комплексном лечении переломов бедра у лиц молодого трудоспособного возраста перспективно использование эфферентной физической терапии. Целью работы было изучить маркеры ремоделирования костной ткани в динамике консолидации перелома бедренной кости в условиях озонотерапии. В исследование были включены 20 мужчин (группа 2, 47,8 \pm 3,5 лет) с переломом диафиза бедренной кости (AO/ASIF 32A, 32B). Контрольную группу (группа 1, 46,8 \pm 3,7 лет) составили 10 здоровых мужчин. Пациентам подгруппы 2а $(n=10)$ проводили стандартное лечение, подгруппы 26 ( $n=10)-$ стандартное лечение и малую аутогемоозонотерапию (МАГОТ) при концентрации озона 20 мг/л. В динамике на 7-е, 30-е, 90-е сутки определяли интенсивность консолидации (по шкале RUST), C-концевые телопептиды коллагена I типа (bCTx, пг/мл) в крови, С-концевой пропептид проколлагена I типа (РICP, нг/Мл). Результаты оценки по шкале RUST в подгруппах 2а и 26 на 7-е сутки - 4 балла, на 30-е сутки - 6,5 и 8,7 баллов, на 90-е - 10 и 11,5 баллов соответственно. На фоне МАГОТ минеральная плотность костной ткани в подгруппе 26 на 90-е сутки достигала 90\% против 78\% в подгруппе 2a, что отражает значимо высокие темпы консолидации. На фоне МАГОТ bСТх на 30-е сутки был выше, чем в подгруппе 2a (соответственно 2289,4 [2145,3; 2365,4] против 1894,6 [1745,3; 2098,2], РІСР значимо повышался в сравнении с подгруппой 2а на 7-е сутки, с максимумом на 30-е и 90-е сутки наблюдения (30-е сутки: 268,3 [231,2; 286,3] против 183,2 [174,6; 195,6], 90-е сутки: 584,6 [512,3; 589,3] против 351,2 [312,3; 369,4]. Применение МАГОТ оказывает позитивное влияние на качество и интенсивность формирования костного регенерата у мужчин с закрытым неосложненным изолированным переломом диафиза бедренной кости.

Ключевые слова: закрытый изолированный перелом диафиза бедра, озонотерапия, маркеры ремоделирования костной ткани

Вклад авторов: М. В. Осиков - концепция и дизайн исследования, анализ полученных данных, написание текста, редактирование рукописи; Е. В. Давыдова - концепция и дизайн исследования, анализ полученных данных, написание текста; К. С. Абрамов - набор клинического материала, анализ результатов, написание текста, редактирование рукописи. Все авторы внесли существенный вклад в проведение исследования и подготовку статьи, прочли и одобрили финальную версию перед публикацией.

Соблюдение этических стандартов: исследование одобрено этическим комитетом Южно-Уральского государственного медицинского университета г. Челябинск (протокол № 4 от 22 мая 2020 г.). Все участники подписали информированное согласие на участие в исследовании.

$\square$ Для корреспонденции: Михаил Владимирович Осиков ул. Воровского, д. 64, г. Челябинск, 454092; prof.osikov@yandex.ru

Статья получена: 29.12.2020 Статья принята к печати: 17.01.2021 Опубликована онлайн: 02.02.2021

DOI: $10.24075 /$ vrgmu.2021.003

Traumatic femoral fractures are among the leading causes of morbidity and mortality in low- and middle-income countries. They typically occur in young, working-age individuals [1, 2]. The need to clarify the pathogenesis of trauma-associated conditions and to develop efferent therapies for restoring the biochemical and immune homeostasis in patients with musculoskeletal injuries underscores the significance of studying bone turnover markers. The standard treatment 
of orthopedic pathology can be complemented by physical therapy, like ozone therapy. Ozone therapy produces a local pain-relieving, anti-edematous, anti-inflammatory and tissueregenerative effect, improves circulation, and exerts systemic immunomodulatory, anti-hypoxic, and redox-state-regulating activity. At the immune system level, ozone therapy stimulates the synthesis of pro- and anti-inflammatory cytokines and growth factors, contributing to tissue healing and remodeling [3]. When administered at therapeutic concentrations, ozone actively participates in the mitochondrial respiratory chain, accelerates glycolysis through the activation of phosphofructokinase and boosts the synthesis of ATP and 2,3-diphosphoglycerate, thereby improving oxygen uptake. It is reported that ozone therapy is effective in treating musculoskeletal disorders, such as rheumatoid arthritis, subacromial and other types of bursitis, osteoarthritis, capsulitis, temporomandibular joint pathology, etc. [4]. According to some authors, intravenous and intraarticular ozone injections benefit patients with osteoarthritis [5]. The aim of this study was to investigate the dynamics of bone turnover markers at different stages of simple (closed) femoral shaft fracture consolidation in the setting of systemic ozone therapy.

\section{METHODS}

This pilot study enrolled 20 male patients admitted to Chelyabinsk Regional Clinical Hospital for isolated closed displaced midshaft femoral fractures coded as 32A or 32B according to the AO/ASIF classification and as S72.3 according to ICD-10 [6]. The mean age of the participants, who formed group 2, was $47.8 \pm 3.5$ years. The following inclusion criteria were applied: age between 35 and 55 years; an isolated closed midshaft femoral fracture sustained 5-7 days before admission. Patients with acute pathology, cancer, lymphoproliferative disorders or osteoporosis were excluded from the study. The control group (group 1) comprised 10 healthy males aged $46.8 \pm 3.7$ years; their levels of bone turnover markers were used as a reference. All patients from group 2 underwent surgery on day 5-7 after the injury. The surgical procedure was performed using the standard surgical approach and involved closed reduction followed by intramedullary fixation with self-locking nails. Postoperatively, both groups received conventional treatment with antibiotics and non-steroid antiinflammatory drugs.

Immediately after the surgical intervention, patients from the main group ( $n=20$, group 2) were randomized into 2 equally sized subgroups $2 \mathrm{a}$ and $2 \mathrm{~b}$ (10 persons per group). Group 2a was assigned to receive standard therapy; group $2 \mathrm{~b}$ was assigned to receive standard therapy complemented by minor autohemotherapy (MAHT), i.e. injections of ozoneenriched autologous blood. The ozone-oxygen mixture (OOM) was prepared using an automated UOTA-60-01 machine (Medozone; Russia) fitted with an ozone destructor. Ozone concentrations in the ozone-oxygen mixture were $20 \mathrm{mg} / \mathrm{L}$. First, the medical grade gas was collected in a $20-\mathrm{ml}$ syringe; then it was combined $10 \mathrm{ml}$ of venous blood drawn from the cubital vein. The blood was combined with OOM by vigorous stirring for 2-3 seconds; the resultant mixture was injected deep into the gluteal or femoral muscles. The regimen consisted of 7-9 injections on alternate days. None of the patients developed adverse reactions to ozone therapy (fever, chills, malaise, infiltration at the injection site).

On admission and during treatment, the severity of pain at the fracture site was assessed using a visual analog scale (VAS) [7]. This scale is an ungraded $10 \mathrm{~cm}$-long line, the left and right ends of which represent no pain and extreme pain, respectively. Pain scores were measured immediately after the surgical procedure, prior to administering pain killers. Postoperatively, general condition was assessed every day; the patients were monitored for a fever and local signs of inflammation (edema, hyperemia, tissue infiltration, wound discharge). The day after surgery, each patient underwent a CT scan to rule out systemic osteoporosis and check the adequacy of the applied surgical technique. The scans were performed using a SOMATOM Definition Edge scanner (Siemens; Germany). Bone mineral density (BMD) measured in the paracortical bone at the fracture site was expressed in Hounsfield units $(H U)$ and compared to $\mathrm{BMD}$ of the cortical bone in the contralateral leg. Follow-up CT scans were performed on days 7, 30 and 90 after the injury. In addition, the RUST scale [8] was applied to assess bone healing in each of 4 cortices (anterior, posterior, medial, lateral). The total score of 4 points was interpreted as the absence of consolidation; the total score of 10-12 points was interpreted as complete bony union. Clinical criteria for consolidation included the absence of edema or soft tissue infiltration and no pain on axial, ipsilateral and rotational loading.

Bone turnover markers were measured in fasting venous blood samples collected on days 7, 30 and 90 after the injury. Bone resorption was assessed from the levels of C-terminal telopeptides of type I collagen (bCTx, Beta-Crosslaps, pg/ml) measured by ELISA (ProteinsAntibodies; Russia). Bone formation was assessed from the levels of procollagen type I carboxy-terminal propeptide (PICP, ng/ml) (ProteinsAntibodies; Russia). The measurements were conducted in a Multiskan Multisoft plate reader (Labsystems Oy; Finland) at the corresponding wavelength.

Statistical analysis was carried out in IBM SPSS Statistics 19 (IBM; USA). Below, the data are presented as median (Me) values and quartiles $\left[Q_{25} ; Q_{75}\right]$. The significance of differences between the groups was assessed with the Wilcoxon, KruskalWallis, Mann-Whitney and Wild-Wolfowitz tests. Correlations between the studied parameters were tested using Spearman's rank correlation coefficient $(\mathrm{R})$. The discovered differences were considered significant at $p<0.05$.

\section{RESULTS}

VAS pain scores measured on days 5-7 after the injury (prior to surgery) were above average (5.6 [4.8-6.4] points), i.e. subjectively the pain was moderately severe, persistent, and

Table 1. Bone mineral density and RUST scores for the periosteal callus in patients with a closed isolated femoral shaft fracture, $\left(M e\left[Q_{25} ; Q_{75}\right]\right)$

\begin{tabular}{|c|c|c|c|c|c|c|c|}
\hline \multirow{2}{*}{ Parameter } & \multirow{2}{*}{$\begin{array}{l}\text { Healthy leg (cortical bone) } \\
\qquad(n=10)\end{array}$} & \multicolumn{6}{|c|}{ Fractured leg, (subgroup 2a, $n=10$ ) } \\
\hline & & \multicolumn{2}{|c|}{ Day 7} & \multicolumn{2}{|l|}{ Day 30} & \multicolumn{2}{|c|}{ Day 90} \\
\hline \multirow{2}{*}{ BMD } & \multirow{2}{*}{1956.5 [1789.5; 2035.8] } & HU units & $\%$ & HU units & $\%$ & HU units & $\%$ \\
\hline & & $0.5^{\star}$ & 0 & 354. $4[327 ; 368.8]^{*}$ & 18 & 1544. $2[1468.2 ; 1632.1]^{*}$ & 1544. $2[1468.2 ; 1632.1]^{\star}$ \\
\hline $\begin{array}{l}\text { Total RUST } \\
\text { score }\end{array}$ & $12.0[12.0 ; 12.0]$ & \multicolumn{2}{|c|}{$4.0[4.0 ; 4.0]^{*}$} & \multicolumn{2}{|l|}{$6.5[5.5 ; 7.0]^{*}$} & \multicolumn{2}{|c|}{$10.0[9.0 ; 11.0]$} \\
\hline
\end{tabular}

Note: * - differences are significant $(p<0.05$; the Mann-Whitney, Kruskal-Wallis, Wilcoxon and Wild-Wolfowitz tests) for comparison with the healthy leg. 
Table 2. Bone mineral density and RUST scores at the site of the periosteal callus in patients with an isolated closed femoral shaft fracture in the setting of ozone therapy $\left(\mathrm{Me}\left[\mathrm{Q}_{25} ; \mathrm{Q}_{75}\right]\right)$

\begin{tabular}{|c|c|c|c|c|c|c|c|}
\hline \multirow{3}{*}{ Paramater } & \multirow{3}{*}{$\begin{array}{l}\text { Healthy leg } \\
\text { (cortical bone) } \\
(n=20)\end{array}$} & \multicolumn{6}{|c|}{ Fractured leg $(n=20)$} \\
\hline & & \multicolumn{2}{|c|}{$\begin{array}{c}\text { Day } 7 \text { (immediately after surgery), } \\
\text { HU, un. (\%) }\end{array}$} & \multicolumn{2}{|c|}{$\begin{array}{c}\text { Day } 30 \\
\text { HU, un. (\%) }\end{array}$} & \multicolumn{2}{|c|}{$\begin{array}{l}\text { Day } 90, \\
\text { HU, un. (\%) }\end{array}$} \\
\hline & & $\begin{array}{c}\mathrm{NoO}_{3} \\
\text { (subgroup 2a) }\end{array}$ & $\begin{array}{c}\text { MAHT } \\
\text { (subgroup 2b) }\end{array}$ & $\begin{array}{c}\mathrm{NoO}_{3} \\
\text { (subgroup 2a) }\end{array}$ & $\begin{array}{c}\text { MAHT } \\
\text { (subgroup 2b) }\end{array}$ & $\begin{array}{c}\mathrm{NoO}_{3} \\
\text { (subgroup 2a) }\end{array}$ & $\begin{array}{c}\text { MAHT } \\
\text { (subgroup 2b) }\end{array}$ \\
\hline BMD & $\begin{array}{c}1956.5 \\
{[1789.5 ; 2035.8]}\end{array}$ & $0.5^{\star}(0 \%)$ & $0.6^{*}(0 \%)$ & $\begin{array}{l}354.4[327.3 \\
368.8](18 \%)^{*}\end{array}$ & $\begin{array}{l}372.8[262.5 ; \\
381.4](19 \%)^{*}\end{array}$ & $\begin{array}{l}\text { 1544. } 2 \text { [1468.2; } \\
\text { 1632.1] }(78.2 \%)^{\star}\end{array}$ & $\begin{array}{c}1825.3[1726.1 ; \\
1911.3] 90 \%\end{array}$ \\
\hline $\begin{array}{l}\text { Total RUST } \\
\text { score }\end{array}$ & $12.0[12.0 ; 12.0]$ & $4.0[4.0 ; 4.0]^{*}$ & $4.0[4.0 ; 4.0]^{*}$ & $6.5[5.5 ; 7.0]^{*}$ & $8.7[5.9 ; 8.9]^{\#}$ & $10.0[9.0 ; 11.0]$ & $11.5[10.5 ; 2.0]^{\#}$ \\
\hline
\end{tabular}

Note: * - differences are significant $(p<0.05$; the Mann-Whitney, Kruskal-Wallis, Wilcoxon and Wild-Wolfowitz tests) for comparison with the healthy leg; \#- differences are significant for comparison with subgroup $2 \mathrm{a}$.

interfered with any activity or mental concentration. The patients could ignore the pain for several minutes at the longest. After the surgical intervention, the pain reached its intensity peak and was assessed as 8-9 points on the visual analog scale. Now, the pain became intense, excruciating, and was a serious constraint on physical activity. According to the CT scans performed on the day after the surgical procedure (i.e., on day 7 after the injury), none of the patients had osteoporosis. No visual signs of inflammation in the affected limb were detected on physical examination. On days 30 and 90, VAS scores were as low as 1.2 [0.9-1.4] and 0.8 [0.6-0.9] points, respectively.

Throughout the entire observation period, bone fragments retained a stable position and no signs of intramedullary nail dislocation were detected on CT scans in both subgroups ( $2 \mathrm{a}$ and $2 \mathrm{~b}$ ) of the main group. On day 7 , the radiographic assessment of BMD showed an almost complete absence of the periosteal callus in subgroup 2a (standard treatment; Table 1), also indicated by the low total score on the RUST scale. On day 30 , the periosteal callus was visualized as a distinct nebulous area of newly formed tissue; its BMD was $18 \%$ (relative to the cortical bone of the healthy contralateral limb). The average RUST score was 6.5, suggesting the ongoing process of callus formation. On day 90 , there were no clinical signs of soft tissue infiltration and no pain on axial, ipsilateral and rotational loading. The callus BMD value was close to that of the cortical bone in the healthy contralateral limb, equaling $78 \%$ on average. The RUST score for fracture consolidation was 10 points, confirming complete bony union.

C-terminal telopeptides of type I collagen (bCTx, BetaCrosslaps) are known markers of bone resorption. They are the products of collagen helix degradation; importantly, collagen makes up 90\% of the bone matrix. Procollagen type I carboxy-terminal propeptide (PICP) is the marker of bone formation; its $\mathrm{C}$ (carboxyl) and $\mathrm{N}$ (amino) termini are cleaved by proteinases, resulting in collagen formation and its integration into the bone matrix. The cleaved $\mathrm{C}$ - and $\mathrm{N}$-terminal fragments join extracellular fluid and enter the bloodstream. PICP levels in the blood are directly proportional to the amount of newly synthesized collagen in the bone. The dynamics of bone turnover markers are shown in Tables 3 and 4.

The analysis of Tables 3 and 4 reveals that bone metabolism (bone resorption and formation) was more active in patients from subgroup $2 \mathrm{a}$ at all stages of the observation period (days $7,30,90)$ than in the healthy males of the same age; this suggests the intensity of metabolic processes throughout the entire healing period.

The standard postoperative therapeutic regimen applied in subgroup 2 a was complemented by systemic ozone therapy (MAHT) in group 2b. Subjectively, on day 7 (immediately after surgery) VAS pain scores in subgroup $2 b$ were as high as in group 2a (8-9 points). By days 30 and 90 , pain intensity in group $2 b$ had declined to its minimal values (1.1 [0.8-1.2] and 0.4 [0.2-0.6], respectively) and did not differ from pain scores in group $2 \mathrm{a}$.

The bone mineral density test showed the absence of the periosteal callus in subgroup $2 \mathrm{~b}$ on day 7 (Table 2); RUST scores reflecting the degree of fracture consolidation were low (4 points). CT findings on day 30 indicated the presence of an actively forming periosteal callus. BMD was $19 \%$ relative to the cortical bone in the healthy contralateral limb and did no differ significantly from BMD values in subgroup $2 a$. The average RUST score (8.7) was also suggestive of active periosteal callus formation. On day 90, the patients from subgroup $2 \mathrm{~b}$ had no pain on axial, ipsilateral and rotational loading. The average RUST score was 11.5, indicating complete bony union. The mineral density of the periosteal callus was about $90 \%$ vs. $78.2 \%$ in subgroup $2 a$ and did not differ significantly from the density of the cortical bone in the healthy contralateral limb, suggesting the stimulating effect of ozone therapy on bone metabolism.

The levels of bone turnover markers also changed following the administration of systemic ozone therapy (see Tables 3 and 4).

On day 30 , bCTx levels (marker of bone resorption) were significantly higher in subgroup $2 \mathrm{~b}$ (ozone therapy) than in subgroup 2a. PICP levels (marker of bone formation) were significantly higher in group $2 \mathrm{~b}$ than in group $2 \mathrm{a}$ starting from day 7 and then on days 30 and 90 . This suggests fast bone tissue repair continuing in the setting of the clinical signs of bony union.

Table 3. Levels of C-terminal telopeptides of type I collagen in patients with an isolated femoral fracture undergoing ozone therapy (Me $\left[Q_{25} ; Q_{75}\right]$ )

\begin{tabular}{|c|c|c|c|c|c|}
\hline \multicolumn{6}{|c|}{$\mathrm{bCTx}, \mathrm{pg} / \mathrm{ml}$} \\
\hline Control group, $n=10$ & $\begin{array}{l}\text { Subgroups of the main group } \\
\qquad(n=20)\end{array}$ & Day of observation & Day 7 & Day 30 & Day 90 \\
\hline \multirow{2}{*}{$\begin{array}{c}355,6 \\
{[324,5 ; 378,6]}\end{array}$} & \multicolumn{2}{|c|}{ Subgroup 2a $(n=10)$} & $\begin{array}{c}1572.3 \\
{[1452.3 ; 1638.4]^{*}}\end{array}$ & $\begin{array}{c}1894.6 \\
{[1745.3 ; 2098.2]^{*}}\end{array}$ & $\begin{array}{c}851.3 \\
{[745.9 ; 870.2]^{\star}}\end{array}$ \\
\hline & \multicolumn{2}{|c|}{ Subgroup 2b MAHT $(n=10)$} & $\begin{array}{c}1505.2 \\
{[1356.2 ; 1624.7]^{\star}}\end{array}$ & $\begin{array}{c}2289.4 \\
{[2145.3 ; 2365.4]^{\star \#}}\end{array}$ & $\begin{array}{c}915 \\
{[868.3 ; 925.4]^{*}}\end{array}$ \\
\hline
\end{tabular}

Note: * — differences are significant $(p<0.05$; the Mann-Whitney, Kruskal-Wallis, Wilcoxon and Wild-Wolfowitz tests) for comparison with the control group; \# differences are significant for comparison with subgroup $2 \mathrm{a}$. 
Table 4. Levels of procollagen type I carboxy-terminal propeptide (PICP) in patients with an isolated femoral fracture undergoing ozone therapy (Me $\left[\mathrm{Q}_{25}\right.$; $\left.\left.\mathrm{Q}_{75}\right]\right)$

\begin{tabular}{|c|c|c|c|c|c|}
\hline \multicolumn{6}{|c|}{$\mathrm{PICP}, \mathrm{ng} / \mathrm{ml}$} \\
\hline Control group, $n=10$ & $\begin{array}{l}\text { Subgroups of the main group } \\
\qquad(n=20)\end{array}$ & Day of observation & Day 7 & Day 30 & Day 90 \\
\hline \multirow{2}{*}{$\begin{array}{c}41.4 \\
{[38.6 ; 43.6]}\end{array}$} & \multicolumn{2}{|c|}{ Subgroup 2a $(n=10)$} & $\begin{array}{c}55.9 \\
{[49.1 ; 76.6]^{\star}}\end{array}$ & $\begin{array}{c}183.2 \\
{[174.6 ; 195.6]^{*}}\end{array}$ & $\begin{array}{c}351.2 \\
{[312.3 ; 369.4]^{*}}\end{array}$ \\
\hline & \multicolumn{2}{|c|}{ Subgroup 2b MAHT $(n=10)$} & $\begin{array}{c}106.5 \\
{[75.3 ; 138.6]^{\star \#}}\end{array}$ & $\begin{array}{c}268.3 \\
{[231.2 ; 286.3]^{\star \#}}\end{array}$ & $\begin{array}{c}584.6 \\
{[512.3 ; 589.3]^{\star \#}}\end{array}$ \\
\hline
\end{tabular}

Note: * - differences are significant $(p<0.05$; the Mann-Whitney, Kruskal-Wallis, Wilcoxon and Wild-Wolfowitz tests) for comparison with the control group; \#- differences are significant for comparison with subgroup $2 \mathrm{a}$.

\section{DISCUSSION}

According to the currently held view, bone tissue is an active, dynamic metabolic system ensuring continuous bone remodeling. Bone healing consists of a few consecutive stages of resorption and repair [9]. During the first 5 days after a traumatic injury, fibroblasts, endothelial cells, leukocytes and monocytes migrate to the injury site and promote necrosis of damaged tissue. At the same time, molecules released by these cells trigger the process of granulation tissue formation; this granulation tissue includes elements of mesenchymal, osseous, cartilage and vascular tissues. Necrosis of dead or damaged cells in soft and bone tissues is accompanied by intense pain. According to the International Association for the Study of Pain (IASP), it is not only the actual tissue damage during a traumatic injury that causes pain but also the inflicted emotional stress which reflects the changed mental state of an injured individual. Pain experienced during high-energy longbone fractures results from the hyperalgesia of the nociceptive system due to the effects exerted by inflammatory mediators (proinflammatory cytokines, chemokines, bradykinin) and the efferent effects of the sympathoadrenal axis.

The outer (the most massive) layer of the callus is derived from the cambium layer of the periosteum rich in fibroblasts, blood vessels and osteoblasts. During the first 5 weeks after a traumatic injury, a fibrocartilage callus is formed. In the next 3 to 4 months, the callus remodels. This process can be distinctly visualized on CT scans and identified during clinical examinations. The intensity of bone metabolism (bone resorption and formation) at all stages of our observation (days $7,30,90$ ) was significantly higher than in the healthy men of the same age. This suggests active metabolic processes unfolding in the bone throughout the entire healing period.

The applied physical therapy (minor autohemotherapy) included in the regimen to complement the standard treatment of a closed femoral shaft fracture produced a number of positive effects on bone healing that were associated with the multimodal properties of molecular ozone derivatives. In minor autohemotherapy with ozonated blood, ozone molecules and their derivatives do not enter the bloodstream, so ozone cannot reach its molecular targets. However, when a small volume of blood is combined with the ozone-oxygen gas in a syringe, ozone molecules start to interact with the unsaturated fatty acids of blood cell membranes and plasma components; this results in the production of aldehydes and hydroperoxides (ozone peroxide) and their subsequent transformation into $\mathrm{H}_{2} \mathrm{O}_{2}$ and 4-hydroxynonenal (4-HNE), one of the most active aldehydes [10, 11]. Endogenous hydrogen peroxide and 4-HNE are secondary messengers that modulate the activity of immune cells and hematopoietic tissue and participate in the regulation of cellular antioxidant systems $[10,11]$. It is known that $\mathrm{H}_{2} \mathrm{O}_{2}$ is capable of entering the cytoplasm of mononuclear cells (monocytes, macrophages) and modulates the activity of the nuclear factor kappa B (NF-кB) [10].

There is ongoing debate about the pluripotent effects of $4-\mathrm{HNE}$ on the immune system that are mediated by the regulatory effect on the NF-kB pathway $[10,11]$. This pathway triggers release of proinflammatory cytokines (TNF $\alpha$, INF $\gamma$, IL1 $\beta$, IL6, and IL8) and expression of proinflammatory genes, such as the cyclooxygenase-2 gene (COX-2) and the inducible nitric oxide synthase gene (iNOS) [10, 11]. The therapeutic dose of $\mathrm{O}_{3}$ blocks NF- $\mathrm{kB}$ signaling, thereby reducing inflammation. The hormetic role of ozone is definitive in the regulation of inflammatory/proinflammatory responses. This underscores the therapeutic potential of ozone against a variety of pathologies.

The literature also mentions the analgesic effect of ozone therapy linked to the ozone derivatives-based oxidative modification of inflammatory mediators involved in the transmission of the nociceptive signal to CNS, balance restoration between pro- and antioxidant systems, and the declining levels of toxic molecular lipid peroxidation products [12]. Our study demonstrates the effects of ozone therapy on the optimization of bone repair confirmed by follow-up CT scans: on day 30, the total RUST score (fracture consolidation) was higher for the group receiving ozone therapy, indicating faster bone healing. However, it was only by day 90 that differences in the periosteal callus BMD between subgroups $2 \mathrm{a}$ (no ozone therapy) and $2 \mathrm{~b}$ had reached statistical significance. The complex biochemical processes unfolding at the hematoma site create the conditions for bone tissue regeneration. Here, the special regulatory role is played by activated $T$ cells and osteoclasts. In bone tissue, the majority of the regulatory mechanisms mediated by the immune system promote bone resorption $[13,14]$. The key role in this process is played by the receptor activator of $N F-\kappa B$ (RANK), its ligand (RANKL) and osteoprotegerin (OPG) responsible for osteoclastogenesis, regulation of bone resorption and bone remodeling at the stages of fracture consolidation [15]. Some studies report that bCTx reaches its peak levels (3 times higher the age norm) 3-4 months after the sustained injury and declines substantially 6 months later [15]. Similar data were obtained during the study of bone turnover markers in patients with concomitant spinal and femoral fractures: the levels of bCTx and other bone resorption markers (OPG and RANKL) peaked at weeks 6-12 after the injury [16]. Some authors hold the opinion that OPG production by osteocytes is required to regulate the balance between bone remodeling and receptor-dependent activation of RANKL [16]. We think that the regulatory role of ozone is mediated by the non-classic secondary messenger 4-HNE and consists in the ability of ozone to modulate bone remodeling [17]. This supposition is indirectly confirmed by the increase in the mineral density of the periosteal callus in patients receiving ozone therapy, elevated bCTx on day 30 (relative to the values 
observed in group 2a) and the increase in PICP levels (bone formation marker) on days 7, 30 and 90, which suggests a higher level of bone tissue metabolism at the earliest stages of bone repair.

Thus, our study demonstrates the positive effect of systemic ozone therapy on bone tissue metabolism at the stages of bone formation in patients with isolated closed femoral shaft fracture, which is indicated by the relative increase in bone mineral density and the high total RUST score reflecting fracture consolidation.

\section{References}

1. Bommakanti K, Feldhaus I, Motwani G, Dicker RA, Juillard C. Trauma registry implementation in low- and middle-income countries: challenges and opportunities. J Surg Res. 2018 Mar; 223: 72-86.

2. Agarwal-Harding KJ, Meara JG, Greenberg SL, Hagander LE, Zurakowski D, Dyer GS. Estimating the global incidence of femoral fracture from road traffic collisions: a literature review. $J$ Bone Joint Surg Am. 2015 Mar 18; 97 (6): e31. DOI: 10.2106/ JBJS.N.00314.

3. Bocci VA. Scientific and medical aspects of ozone therapy. State of the art. Arch Med Res. 2006; 37: 425-35.

4. Omar Seyam, Noel L. Smith, Inefta Reid, Jason Gandhi, Wendy Jiang, Sardar Ali Khan. Clinical utility of ozone therapy for musculoskeletal disorders. Med Gas Res. 2018 Jul-Sep; 8 (3): 103-10.

5. Manoto SL, Maepa MJ, Motaung SK. Medical ozone therapy as a potential treatment modality for regeneration of damaged articular cartilage in osteoarthritis. Saudi J Biol Sci. 2018 May; 25 (4): 672-9.

6. Pomogaeva EV, redaktor. Sovremennye klassifikacii perelomov kostej nizhnej konechnosti. Ekaterinburg: Izd-vo UGMU, 2016; 56 s. Russian.

7. Huskisson EC. Measurement of pain. The Lancet. 1974; 9 (2): 1127-31

8. Leow JM, Clement ND, Tawonsawatruk T, Simpson CJ, Simpson RW The radiographic union scale in tibial (RUST) fractures. J Bone \& Joint Research. 2016; 5 (4): 116-21.

9. Hismatullina ZN. Factors influencing the metabolism of bone tissue and leading to diseases of the bone system. Bulletin of the Kazan technological University. 2015; 22. Available from: https://cyberleninka.ru/article/n/faktory-okazyvayuschie-vliyaniena-metabolizm-kostnoy-tkani-i-privodyaschie-k-zabolevaniyamkostnoy-sistemy (data obrashhenija: 20.12.2020). Russian.

10. Bernardino C, Martínez-Sánchez FG, Llontop P, Aguiar-Bujanda D, Fernández-Pérez R, Santana-Rodríguez N. Modulation of Oxidative Stress by Ozone Therapy in the Prevention and Treatment of Chemotherapy-Induced Toxicity: Review and

\section{Литература}

1. Bommakanti K, Feldhaus I, Motwani G, Dicker RA, Juillard C. Trauma registry implementation in low- and middle-income countries: challenges and opportunities. J Surg Res. 2018 Mar; 223: 72-86.

2. Agarwal-Harding KJ, Meara JG, Greenberg SL, Hagander LE, Zurakowski D, Dyer GS. Estimating the global incidence of femoral fracture from road traffic collisions: a literature review. $J$ Bone Joint Surg Am. 2015 Mar 18; 97 (6): e31. DOl: 10.2106/ JBJS.N.00314

3. Bocci VA. Scientific and medical aspects of ozone therapy. State of the art. Arch Med Res. 2006; 37: 425-35.

4. Omar Seyam, Noel L. Smith, Inefta Reid, Jason Gandhi, Wendy Jiang, Sardar Ali Khan. Clinical utility of ozone therapy for musculoskeletal disorders. Med Gas Res. 2018 Jul-Sep; 8 (3): 103-10.

5. Manoto SL, Maepa MJ, Motaung SK. Medical ozone therapy as a potential treatment modality for regeneration of damaged articular

\section{CONCLUSION}

Our study reached its goal and showed that systemic ozone therapy used as an adjunct to the standard treatment regimen for a closed isolated femoral shaft fracture produces a positive effect on the quality and intensity of bone repair, leading to significant changes in BMD, a higher total RUST score, and faster bone remodeling. MAHT can be used as an auxiliary method of efferent physical therapy in the combination treatment of the abovementioned pathology.

Prospects Antioxidants (Basel). 2019 Dec; 8 (12): 588. DOl: 10.3390/antiox8120588.

11. Bocci V, Valacchi G. Nrf2 activation as target to implement therapeutic treatments. Front Chem. 2015; 3: 4.

12. Osikov MV, Davydova EV, Abramov KS. Innate immunity in isolated femoral fractures. Modern problems of science and education. 2019; 1. Available from: http://www.science-education.ru/article/ view?id=28540 (data obrashhenija: 20.01.2020). Russian

13. Korshunova AC, Yuryevna E, Lebedev VF. The role of interferons in the regulation of osteogenic and osteoresorptive processes. Acta Biomedica Scientifica. 2012; 5-2 (87). Available from: https://cyberleninka.ru/article/n/rol-interferonov-v-regulyatsiiosteogennyh-i-osteorezorbtivnyh-protsessov.

14. Mashejko IV. Biohimicheskie markery $v$ ocenke processov remodelirovanija kostnoj tkani pri osteopenii i osteoporoze. Zhurnal GrGMU. 2017; 2. Available from: https://cyberleninka.ru/article/n/ biohimicheskie-markery-v-otsenke-protsessov-remodelirovaniyakostnoy-tkani-pri-osteopenii-i-osteoporoze (data obrashhenija: 01.12.2020). Russian

15. Aganov DS, Tyrenko W, Cygan EN, Toporkov MM, Bologov SG. Rol' citokinovoj sistemy RANKL/RANK/OPG v reguljacii mineral'nogo obmena kostnoj tkani. Geny i kletki. 2014; 4. Available from: https://cyberleninka.ru/article/n/rol-tsitokinovoysistemy-rankl-rank-opg-v-regulyatsii-mineralnogo-obmenakostnoy-tkani (data obrashhenija: 20.12.2020). Russian.

16. Sousa K, Dias I, Lopez-Peña M, Camassa J, Lourenço P. Bone turnover markers for early detection of fracture healing disturbances: A review of the scientific literature. Annals of the Brazilian Academy of Sciences. 2015; 87 (2): 1049-1061. Available from: http://dx.doi.org/10.1590/0001-3765201520150008.

17. Thakkar P, Naveen B. Prakash, Tharion G, Shetty Sh, Paul V, Bondu J, Yadav B. Evaluating Bone Loss with Bone Turnover Markers Following Acute Spinal Cord InjuryAsian Spine Journal 2020; 14 (1): 97-105. Available from: https://doi.org/10.31616/ asj.2019.0004.

cartilage in osteoarthritis. Saudi J Biol Sci. 2018 May; 25 (4): 672-9.

6. Помогаева Е. В., редактор. Современные классификации переломов костей нижней конечности. Екатеринбург: Изд-во УГМУ, 2016; 56 c.

7. Huskisson EC. Measurement of pain. The Lancet. 1974; 9 (2): 1127-31.

8. Leow JM, Clement ND, TawonsawatrukT, Simpson CJ, Simpson RW. The radiographic union scale in tibial (RUST) fractures. J Bone \& Joint Research. 2016; 5 (4): 116-21.

9. Хисматуллина 3. Н. Факторы, оказывающие влияние на метаболизм костной ткани и приводящие к заболеваниям костной системы. Вестник Казанского технологического университета. 2015; 22. Доступно по ссылке: https:// cyberleninka.ru/article/n/faktory-okazyvayuschie-vliyanie-nametabolizm-kostnoy-tkani-i-privodyaschie-k-zabolevaniyamkostnoy-sistemy (дата обращения: 20.12.2020). 
10. Bernardino C, Martínez-Sánchez FG, Lontop P, Aguiar-Bujanda D, Fernández-Pérez R, Santana-Rodríguez N. Modulation of Oxidative Stress by Ozone Therapy in the Prevention and Treatment of Chemotherapy-Induced Toxicity: Review and Prospects Antioxidants (Basel). 2019 Dec; 8 (12): 588. DOI: 10.3390/antiox8120588

11. Bocci V, Valacchi G. Nrf2 activation as target to implement therapeutic treatments. Front Chem. 2015; 3: 4

12. Осиков М. В., Давыдова Е. В., Абрамов К. С. Врожденный иммунитет при изолированных переломах бедренной кости. Современные проблемы науки и образования. 2019; 1. Доступно по ссылке: http://www.science-education.ru/article/ view?id=28540 (дата обращения: 20.01.2020).

13. Korshunova AC, Yuryevna E, Lebedev VF. The role of interferons in the regulation of osteogenic and osteoresorptive processes. Acta Biomedica Scientifica. 2012; 5-2 (87). Available from: https://cyberleninka.ru/article/n/rol-interferonov-v-regulyatsiiosteogennyh-i-osteorezorbtivnyh-protsessov.

14. Машейко И. В. Биохимические маркеры в оценке процессов ремоделирования костной ткани при остеопении и остеопорозе. Журнал ГрГМУ. 2017; 2. Доступно по ссылке: https://cyberleninka.ru/article/n/biohimicheskie-markeryv-otsenke-protsessov-remodelirovaniya-kostnoy-tkani-priosteopenii-i-osteoporoze (дата обращения: 01.12.2020).

15. Аганов Д. С., Тыренко В. В., Цыган Е. Н., Топорков М. М., Бологов С. Г. Роль цитокиновой системы RANKL/RANK/OPG В регуляции минерального обмена костной ткани. Гены и клетки. 2014; 4. Доступно по ссылке: https://cyberleninka.ru/ article/n/rol-tsitokinovoy-sistemy-rankl-rank-opg-v-regulyatsiimineralnogo-obmena-kostnoy-tkani (дата обращения: 20.12.2020).

16. Sousa K, Dias I, Lopez-Peña M, Camassa J, Lourenço P. Bone turnover markers for early detection of fracture healing disturbances: A review of the scientific literature. Annals of the Brazilian Academy of Sciences. 2015; 87 (2): 1049-1061. Available from: http://dx.doi.org/10.1590/0001-3765201520150008.

17. Thakkar P, Naveen B. Prakash, Tharion G, Shetty Sh, Paul V, Bondu J, Yadav B. Evaluating Bone Loss with Bone Turnover Markers Following Acute Spinal Cord InjuryAsian Spine Journal 2020; 14 (1): 97-105. Available from: https://doi.org/10.31616/ asj.2019.0004. 